\title{
A socio-eco-efficiency analysis of integrated and non-integrated crop-livestock-forestry systems in the Brazilian Cerrado based on LCA
}

\author{
Marcela P. Costa ${ }^{\text {a, c, * }}$, Jan C. Schoeneboom ${ }^{\text {b }}$, Sueli A. Oliveira ${ }^{d}$, Rafael S. Viñas ${ }^{\text {a }}$, \\ Gerson A. de Medeiros ${ }^{\text {, *** }}$ \\ ${ }^{a}$ FEE - Fundação Espaço ECO ${ }^{\circledR}$, BASF SA, Estrada Ribeirão Soldado, 230, Botujuru, 09822 010, São Bernardo do Campo, SP, Brazil \\ ${ }^{\mathrm{b}}$ BASF SE, Sustainability Strategy, CDS/S - C104, 67056, Ludwigshafen, Germany \\ ' São Paulo State University (Unesp), Institute of Science and Technology, Av. Três de Março 511, 18087-180, Sorocaba, SP, Brazil \\ ${ }^{\mathrm{d}}$ Universidade Federal do ABC, Center of Engineering, Modelling ans Applied Social Sciences - Avenida dos Estados, 5001, Bairro Santa Terezinha, Santo \\ André, SP, CEP: 09210-580, Brazil
}

\section{A R T I C L E I N F O}

\section{Article history:}

Received 5 June 2017

Received in revised form

13 September 2017

Accepted 7 October 2017

Available online 9 October 2017

\section{Keywords:}

Sustainable development

Environmental fingerprints

Climate change potential

Social impact assessment

Economic assessment

\begin{abstract}
A B S T R A C T
Crop-livestock-forest (CLFi) and crop-livestock (CLi) systems are among the most recent agricultural developments in Brazil, and aligned with the principles of cleaner production. Such integrated systems can provide at least three types of product from the same land area over a defined period. This paper presents a holistic sustainability evaluation using life cycle assessment to compare combinations of integrated and conventional systems in the Brazilian Cerrado region. The study assesses a comprehensive set of indicators in the three sustainability dimensions: environmental, economic, and social (socio-ecoefficiency). By prioritizing CLFi, the production area to meet the demand of grains, meat and energy for 500 Brazilians, from 2007 to 2014, reached 70 ha, while the conventional systems would need 420 ha to meet the same demand. This result shows that it is possible to increase production to meet the growing food global demand without the need of expanding the agricultural frontier, preserving the remaining forestland. CLFi combinations systems decreased $55 \%$ in climate change potential $\left(2389 \mathrm{t}\right.$ of $\mathrm{CO}_{2}$ equivalent), when compared to the conventional systems. It was also observed that the more integrated systems improved the quality of employment, promoted future generation investments in society, and decreased the total production costs in $54 \%$, when compared to conventional systems. Therefore, intensification achieved through good practices such as association, rotation, and succession by an agroforestry system, optimization of inputs (including water, energy, fertilizers, and crop protection agents), land use, soil quality, biodiversity and social aspects.
\end{abstract}

() 2017 Elsevier Ltd. All rights reserved.

\section{Introduction}

The world's demand for food is increasing, with recent studies forecasting that the global population will reach 9.5 billion people by 2050 . This increasing demand requires a corresponding increase of global food production, which is estimated to grow by $60 \%$, based on world production data from 2005 to 2007 (Alexandratos and Bruinsma, 2012). In recent years, food consumption habits have

\footnotetext{
* Corresponding author. FEE - Fundação Espaço ECO ${ }^{\circledR}$, BASF SA, Estrada Ribeirão Soldado, 230, Botujuru, 09822 010, São Bernardo do Campo, SP, Brazil.

** Corresponding author.

E-mail addresses: cmarcelaporto@gmail.com (M.P. Costa), jan.schoeneboom@ basf.com (J.C. Schoeneboom), sueli.oliveira@basf.com (S.A. Oliveira), rafael.vinas@ basf.com (R.S. Viñas), gerson@sorocaba.unesp.br (G.A. de Medeiros).
}

changed especially in the emerging economies of East and West Asia, North Africa, and Latin America. In these regions, higher purchasing power has led to increased consumption and greater demand for processed foods, meat, dairy products, and fish (Godfray et al., 2010). Ultimately, these societies may follow the consumption trajectory of the United States, where per capita meat consumption was $120 \mathrm{~kg}$ per year in 2013 (FAOSTAT, 2015).

In this scenario of growing food demand, Brazil plays a globally important role as a crop and livestock producer. In 2010, the country was the fifth largest producer of cereals and oilseeds, the second largest producer of citrus, and the second largest producer of beef. Comparative studies of competitive export markets show that Brazil has an advantage over certain other emerging countries, due to factors such as economic and social incentive policies, large areas of degraded land available for recovery and production, and 
abundant natural resources (FAO, 2014).

Despite the challenge to increase food production, Brazil is committed to reducing deforestation and greenhouse gas (GHG) emissions (Lapola et al., 2017). There are also economic and social factors that limit increases of production and productivity (Godfray et al., 2010). Examples are limited access to loans, lack of appropriate legislation for rural workers, lack of availability of qualified labor, lack of technological assistance, and poor logistics infrastructure, all of which restrict the possibility of increasing agricultural productivity and efficiency.

Emerging agricultural concepts intended to address these demands include improvements in sustainability and the implementation of ecologically correct techniques. The former aims to increase yields without negative environmental impacts, using the current agricultural area (Andres and Bhullar, 2016); the latter consists of minimizing impacts by the integration of ecosystem services management into crop and livestock production (Bommarco et al., 2013). Sustainable intensification in this context considers the biophysical, social, cultural, and economic background, with selection of the optimal mix of approaches for agricultural production (Garnett and Godfray, 2012).

In Brazil, sustainable soil management and crop techniques have the potential to recover previously unproductive areas in tropical and sub-tropical environments, as exemplified by the integrated crop-livestock (CLi) and crop-livestock-forest (CLFi) systems developed by EMBRAPA (Brazilian Corporation for Agricultural Research). Integrated systems can combine crop production, livestock, and forestry, supporting the production of at least three types of product from the same land area over a defined period. Examples are soy, maize, silage, sorghum, cattle and eucalyptus, among others. These systems, based on intercropping, succession, and/or rotation, can optimize the biological cycling of nutrients between plants and animals, improving production efficiency and maintaining long-term soil fertility. For example, an integrated system includes tropical forage plants, which replenish soil organic matter, recycle nutrients underground, and contribute to biological plowing and microbial activity due to their extensive root systems. These and other effects provide environmental benefits; reducing damage to the biota, improving conditions for the maintenance of crop health, and consequently decreasing the need for pesticides (Balbino et al., 2012). Economic benefits include lower implementation and maintenance costs, compared to conventional systems, with greater profitability and product quality. Social benefits are due to the jobs created directly and indirectly from the use of such systems, as well as decreased migration out of rural areas (Aidar and Kluthcouski, 2003).

In summary, these systems are able to recover degraded areas at relatively low cost, producing three times the volume of grain and twice the volume of meat, without any need to open up new areas, optimizing land use while at the same time providing social benefits (EMBRAPA, 2013).

Currently, producers who practice the recovery of degraded pastures by means of the no-tillage system (NT), employ biological nitrogen fixation, plant forests, actively manage the use of animal manure, or employ crop-livestock-forest integration are eligible for government incentives under the low-carbon agriculture initiative (ABC Plan), coordinated by the Ministry of Agriculture, Livestock and Supply (MAPA).

Studies investigating the environmental impacts of CLi, CLFi and conventional systems have so far mainly addressed selected aspects as soil quality (Martins et al., 2017; Oliveira, 2010), greenhouse gas balance (de Figueiredo et al., 2017; Cerri et al., 2016) and water footprint (Scarpare et al., 2016). However, studies to evaluate the efficiency of these systems, considering social, economic and environmental aspects in a comprehensive way, are still scarce in the literature (Costa et al., 2014).

A comprehensive approach for determining the environmental performance of products or systems is Life Cycle Assessment (LCA), which aims to identify and understand opportunities to enhance the environmental performance of products or systems during their life cycle, supporting decision makers and assisting in the development of public policies (Paes et al., 2014). In the past decade, LCA has been applied to complex issues involving the influence of crop and animal production systems on land use change, biodiversity, biotic resource depletion, water use, soil quality, and emissions modeling (van der Werf et al., 2014; Ogino et al., 2016). However, comparison of the environmental efficiencies of integrated and conventional systems using quantitative methods such as LCA can be challenging, especially due to synergic effects among the system components and need for allocation across multiple products. Furthermore, broader ecosystem services that are not well represented in standard LCA approaches need special consideration in order to achieve a holistic assessment.

AgBalance methodology (Schoeneboom et al., 2012a) is a tool used to make inferences about sustainability in agriculture, and based on socio-eco-efficiency analysis. Socio-eco-efficiency includes social parameters, such as child labor, community impacts and qualification of employees with guidelines for ecoefficiency. The AgBalance ${ }^{\mathrm{TM}}$ allows performing an extensive evaluation, showing no limitations concerning the geographic region or the intensity of the processes to be analyzed. With the ability to evaluate multiple systems, products and processes, AgBalance ${ }^{\mathrm{TM}}$ tool makes use of over 200 criteria for the construction of 69 indicators (Schoeneboom et al., 2012a).

The present study evaluates the socio-eco-efficiency of five different integrated and non-integrated combinations of annual crops (soy, corn, and sorghum), forestry (eucalyptus for energy supply), and cattle production systems, using the LCA approach.

In this way, we used AgBalance methodology, and a life cycle inventory was developed in a productive farm in Brazilian Cerrado region, in Goiás state, Brazil. The aim is to contribute to a better understanding of the impacts and benefits of integrated farming systems in the Brazilian Cerrado, considering environmental, social and economic aspects.

\section{Methods}

\subsection{LCA and socio-eco-efficiency: assessment model}

Life cycle assessment (LCA) is a method used to assess the environmental impacts of a product or a system throughout its life cycle. The approach is also suitable for identifying opportunities to enhance the environmental performance of products or systems during their life cycle, and for informing decision makers (ISO, 2009a, 2009b).

Socio-eco-efficiency analysis (SEE) (Saling et al., 2002) integrates environmental LCA with economic and social sustainability metrics. AgBalance ${ }^{\mathrm{TM}}$ (Schoeneboom et al., 2012a) is a specific implementation of SEE; the environmental evaluation additionally considers biodiversity and soil quality metrics specifically for assessment of agricultural sustainability. AgBalance ${ }^{\mathrm{TM}}$ also calculates single score results for environmental, social, and economic sustainability indicators by normalization and weighting. AgBalance ${ }^{\mathrm{TM}}$ was used in this study as the assessment model because it is a SEE model that in addition to the LCA approach also includes indicators for biodiversity and soil quality, which are relevant in the context of assessment of integrated and conventional agricultural systems. 


\subsection{Functional unit definition and systems studied}

The definition of a functional unit must take into account the context of a product and the technological options available on the market to perform the same or similar function of the product (Krozer and Vis, 1998); for the present study, it was necessary to find a comparative basis that accounted for the multiple products produced by the systems. In order to avoid allocation of environmental and social burdens among the various products (and in order to respect the synergistic effects of integrated systems), it was decided to establish a composite functional unit, that would better describe the functionality of the whole system in terms of energy supply (both in the form of the edible products soy, corn, sorghum and beef, or in the form of one of the energy sources that compound the Brazilian electricity mix, as wood). The technological reference unit (TRU) capability of the providing such products, considering their respective productivities along the whole production cycle of the integrated system, was established as the baseline for defining the adopted functional unit. In this study TRU was the Santa Brigida Farm (SBF), described in section 2.3.

According to Brazilian consumption data for the period from 2007 to 2014 (FAOSTAT, 2015; EMBRAPA, 2010; BRASIL. Ministério de Minas e Energia, 201), as shown in Table 1, around 500 people could be benefited with the referred items, in the quantities provided by the TRU.

Therefore, the functional unit was established as the provision of sufficient soy, corn, sorghum, meat, and wood to meet the food and energy demand of an average Brazilian population sample of 500 people during a 7-year production cycle, since that is the timeframe for the eucalyptus cycle, the longest productive cycle of the integrated system. The amount of 500 people was chosen because it is the amount of people which CLFI system at SBF ( $50 \mathrm{ha}$ ) can supply at this period. Thus, the LCA results are an approximation to the impacts that were generated on the farm level.

The choice of alternative agricultural production systems considered viable farming practices, given the main technological options available in the Brazilian Cerrado biome. Assumptions and boundary conditions were based on the socio-economic conditions and environmental characteristics of the chosen location.

Table 2 lists the production outputs of the integrated and nonintegrated production systems considered in this study. A detailed description of the various systems is provided in the Supporting Information.

Table 1

Functional unit to meet the food and energy demand of 500 Brazilians from 2007 to 2014.

\begin{tabular}{ll}
\hline Product & Amount $(\mathrm{t})$ \\
\hline Soy & 263.5 \\
Corn & 384.0 \\
Sorghum & 19.0 \\
Meat & 132.7 \\
Wood & 1535.3 \\
\hline
\end{tabular}

It was necessary to determine a reference flow (Table 3) so that the alternatives compared produced the same quantities of soy, corn, sorghum, meat and wood, consistent with the functional unit established. Hence, the alternatives were multiproduct combinations in which one dominant cultivation system made the major contribution to the final output in each combination.

Alternative 3 consisted only of conventional production systems. Alternative 1 used CLFi combined with conventional production, and alternative 2 used CLi and conventional production. Alternatives 4 and 5 combined different ratios of CLFi and CLi with conventional production. Alternative 4 was the system that used the smallest land area, and could be viewed as the most highly integrated system. In contrast, alternative 3 (conventional systems only) required the largest production area.

\subsection{Description of the study location}

All the systems compared in the analysis were located in the municipality of Ipameri, State of Goiás, Brazil. Primary data for the integrated systems were collected from Santa Brígida farm, where CLFi and CLi systems had been consolidated over a period of 7 years. Primary data for the conventional systems were sourced from neighboring farms (Costa, 2012). A detailed documentation of each product system is available in the Supporting Information (Table A1 to A.28). For the economic evaluation of each of the alternatives, the total costs of production were calculated based on the primary data.

Secondary data for environmental and social aspects were collected for the upstream processes, including industrial manufacturing of inputs and transportation. The secondary data were extracted from official publications, government technical reports (AGRIANUAL, 2010; IBGE, 2015), and international databases such as public and commercial LCA databases, as ecoinvent 2.2 (Nemecek and Kägi, 2007) and Boustead Model 5.1 (BOUSTEAD, 2013).

Santa Brígida farm is located in the Cerrado biome, at $17^{\circ} 39^{\prime}$ 29.47" S, $48^{\circ} 12^{\prime} 23.51$ " W (headquarters), $810 \mathrm{~m}$ above sea level. The soil of the area is a dark red latossol. Although it is naturally acid and presents low fertility, it provides good drainage, with an

Table 3

Reference flow showing five different combinations of farming systems (in terms of area) used to supply the functional unit.

\begin{tabular}{llllll}
\hline \multirow{2}{*}{ Systems } & \multicolumn{7}{l}{ Alternatives } \\
\cline { 2 - 6 } & 1 & 2 & 3 & 4 & 5 \\
\cline { 2 - 6 } & ha & & & & \\
\hline CLFi & 51.4 & 0.0 & 0.0 & 50.0 & 25.0 \\
CLi & 0.0 & 10.3 & 0.0 & 1.3 & 6.8 \\
Conventional crop (soy) & 8.7 & 4.4 & 13.7 & 7.6 & 5.2 \\
Conventional crop (corn) & 5.3 & 0.0 & 20.0 & 3.1 & 0.0 \\
Conventional crop (sorghum) & 6.3 & 0.0 & 6.3 & 5.5 & 2.2 \\
Conventional livestock & 0.0 & 291.7 & 369.3 & 0.0 & 139.0 \\
Conventional eucalyptus & 1.8 & 9.7 & 9.7 & 2.0 & 5.8 \\
Total & 73.5 & 316.2 & 419.0 & 69.6 & 184.0 \\
\hline
\end{tabular}

Table 2

Production outputs from 50 ha of each farming system during seven years.

\begin{tabular}{|c|c|c|c|c|c|}
\hline \multirow[t]{2}{*}{ Product } & CLFi & CLi & Conventional crop & Conventional livestock & Conventional eucalyptus \\
\hline & \multicolumn{5}{|l|}{$\mathrm{t}$} \\
\hline Soy & 94.3 & 870.0 & 960.0 & - & - \\
\hline Corn & 274.9 & 1824.0 & 960.0 & - & - \\
\hline Sorghum & - & 91.6 & 150.0 & - & - \\
\hline Beef & 129.1 & 135.0 & - & 18.0 & - \\
\hline Wood & 1221.1 & - & - & - & 7926.8 \\
\hline
\end{tabular}


average clay content of 45\% (Oliveira, 2010; EMBRAPA, 2013). The climate, according to the Köppen classification, is the AW type, corresponding to mesothermal tropical savanna (Oliveira, 2010).

Santa Brígida farm became a Technological Reference Unit (TRU), established by EMBRAPA, with implementation of the croplivestock-forest integrated system. Up until 2005, the farm mainly produced conventional livestock. However, since the implementation of integrated systems in 2006, the farm has been producing, in the same area, several products including soy, corn (grain and silage), sorghum, beef, and wood, with high productivity (Costa, 2015).

\subsection{Inventory methods and assumptions}

An attributional life cycle inventory method was employed in the present study. Consequential LCA was considered unnecessary for the objectives and intended use of the work, because it is aimed at retrospective or descriptive comparisons of the production systems.

A common growing protocol was assumed for all cropping systems, defining use of fertilizers and crop protection applications and practices. The systems were no-tillage, except for the first year of the 7-year production cycle. Livestock production always comprised fattening from calf to the mature animal, and calculations used the same basic assumptions (for details, see the Supporting Information). However, there were differences in livestock fattening in the integrated systems, which made use of different kinds of complementary feeds, according to the age of the cattle and the season of the year, while no complementary feed was used in the conventional system.

Methane (CH4) emissions from enteric fermentation and livestock manure were calculated according to the Intergovernmental Panel on Climate Change (IPCC) tier 1 approach (IPCC, 2006). Manure from grazing and confined animals was returned to the pasture system as fertilizer (nutrient cycling). Gaseous emissions of $\mathrm{N} 2 \mathrm{O}, \mathrm{NO}, \mathrm{NH} 3$, and $\mathrm{CO} 2$ from fertilizer applications were modeled based on emission factors from IPCC tier 1 (IPCC, 2006). The emission factor of $\mathrm{N}$ to surface water bodies was assumed to be $10 \%$ of applied N.

Drinking water for cattle was considered to be $100 \%$ for consumption, since it was either incorporated in slurry and manure or consumed in other ways by the animals. The fraction of water applied to agricultural fields with slurry was considered to be transferred to other watersheds and lost through evapotranspiration. At Santa Brigida Farm, all crops were non-irrigated (Costa, 2015). Water consumption in the industrial manufacture of fertilizers was modeled on the basis of consumption of $1 \%$ of the cooling water used in the chemical plants.

\subsection{Life cycle impact assessment method}

The environmental assessment was based on established life cycle impact assessment (LCIA) mid-point indicators, as used in eco-efficiency analysis (Saling et al., 2002) and a wide range of other LCA approaches. The environmental impact categories were: abiotic resource depletion (Saling et al., 2002), climate change (IPCC, 2007), primary energy consumption (Saling et al., 2002), acidification potential (CML, 2010), photochemical ozone creation (CML, 2010), freshwater eutrophication (Goedkoop et al., 2013), marine eutrophication (Goedkoop et al., 2013), water scarcity (Pfister et al., 2009), freshwater eco-toxicity (Rosenbaum et al., 2008) and land use (Köellner and Scholz, 2007, 2008).

Additionally, environmental indicators addressing the specific impacts of agricultural activity on biodiversity, and on soil health and conservation were incorporated into the methodology. The potential impact on biodiversity was assessed using eight indicators related to the state of biodiversity, crop management practice (crop rotation, eco-toxicity potential of crop protection products, nitrogen surplus) and the environmental policy context (availability of protected areas or agri-environmental schemes). The soil health impact category consisted of indicators for the soil organic matter balance, soil erosion, soil compaction, and the balances of the nutrients $\mathrm{N}, \mathrm{P}$, and $\mathrm{K}$.

The social assessment in AgBalance ${ }^{\mathrm{TM}}$ was derived from the SEEBALANCE method for social LCAs, which was developed in 2005 by the Universities of Karlsruhe and Jena, the Öko-Institut e.V. (Institute for Applied Ecology, Freiburg) and BASF (Kölsch et al., 2008; Schmidt et al., 2004). Based on the UNEP-SETAC guidelines for social LCAs of products, five stakeholder categories were defined: employees, consumers, local and national communities, the international community and future generations. The SEEBALANCE indicators and data sources were employed to assess the social impacts of upstream and downstream industrial processes. For the agricultural activities in the life cycle, social impact indicators were selected from the AgBalance ${ }^{\mathrm{TM}}$ method (Schoeneboom et al., 2012a, 2012b).

\section{Results and discussion}

Aggregated scores for the different alternatives in terms of environmental, social, economic and overall performance are shown in Fig. 1. The best overall sustainability score, according to the scope of this study, was found for the most integrated combination (alternative 4), while the worst score was for the purely conventional combination (alternative 3 ). The results generally showed that the best systems were those with a higher contribution of CLFi, followed by those with a higher contribution of CLi. The following sections provide a detailed breakdown of the scores,
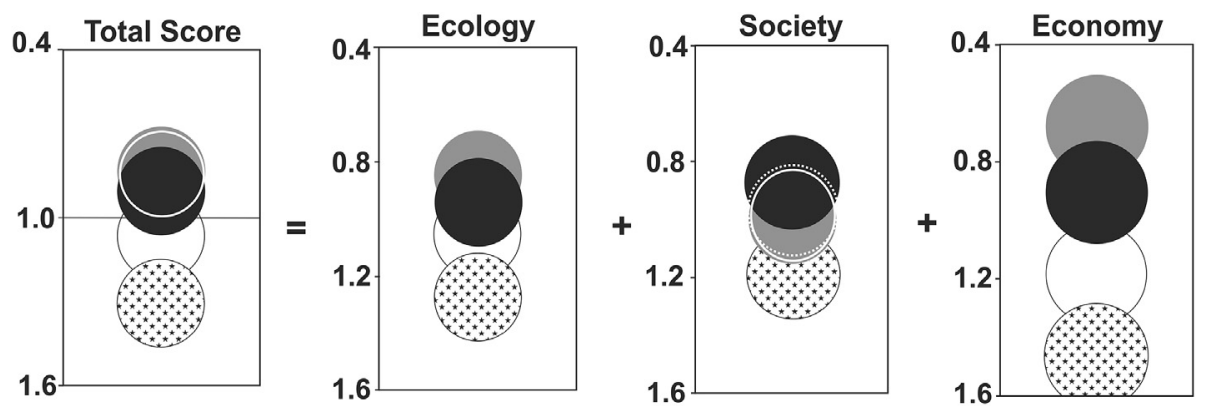

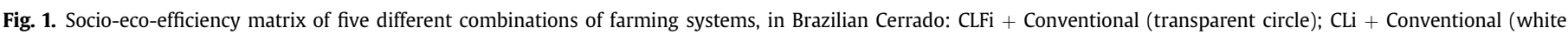
circle); Conventional (starry circle); CLFi + CLi + Conventional (1) (grey circle); CLFi + CLi + Conventional (2) (black circle). 
considering the underlying impact indicators. The normalization and weighting factors used in calculation of the scores are described in section 3.1.1.

Sensitivity analysis (results in Supporting Information, Figure A1) showed that the aggregated sustainability score is most sensitive with respect to parameters for amounts of inputs, such as fertilizers, pesticides and fuels (which in turn influence emissions). Increasing the amount of inputs for the most integrated systems (alternatives 1 and 4 ) by up to $50 \%$ over the base case did not change the rank order of these alternatives over the conventional system (alternative 3 ). The conclusion that the integrated systems achieve a better total score for the present scope of the study thus may be considered as robust.

\subsection{Environmental fingerprints}

The environmental fingerprints (Fig. 2) provided insights into the strengths and weaknesses of the different alternatives, based on the different impact categories, enabling analysis of the tradeoffs between alternatives. Compared to the conventional system (alternative 3), the alternatives using integrated systems presented higher impacts in two categories: freshwater eco-toxicity potential and abiotic resource depletion. In all other environmental categories (cumulative energy consumption, emissions, land use, water use, biodiversity and soil), the impacts were lowest for the most integrated combination (alternative 4), followed by the alternatives with higher contributions of CLFi and CLi. The conventional systems (alternative 3) always showed the worst performance in these categories.

\subsubsection{Normalization and weighting factors}

The several impact category indicators are aggregated to single scores by normalization and weighting. Effective weighting factors are listed in Table 4; they were calculated per indicator from a relevance factor and a social weighting factor (Saling et al., 2002); a mathematical derivation is given in the Supporting Information. The relevance factor is calculated by external normalization, this means that the impact indicator result of the system under study (per functional unit) is divided by the total impact generated in the geographic territory of Brazil in one year (IBGE, 2015). From the various systems investigated in the present study, the highest relevance factor per impact category was selected, and the set of factors for the several impacts were brought to a percent scale. The resulting relevance weights are displayed in column 2 of Table 4 (environmental relevance factor). The missing entries (Ecotoxicity potential, Biodiversity, Soil) could not be obtained, due to lack of reference data for the national total annual impact.

The social weighting factors for each environmental impact category were raised by TNS Infratest, an expert in market research and polling, in a study commissioned by BASF through representative international polls and expert interviews in 2011. The societal factors guarantee that society's views and opinions are reflected in

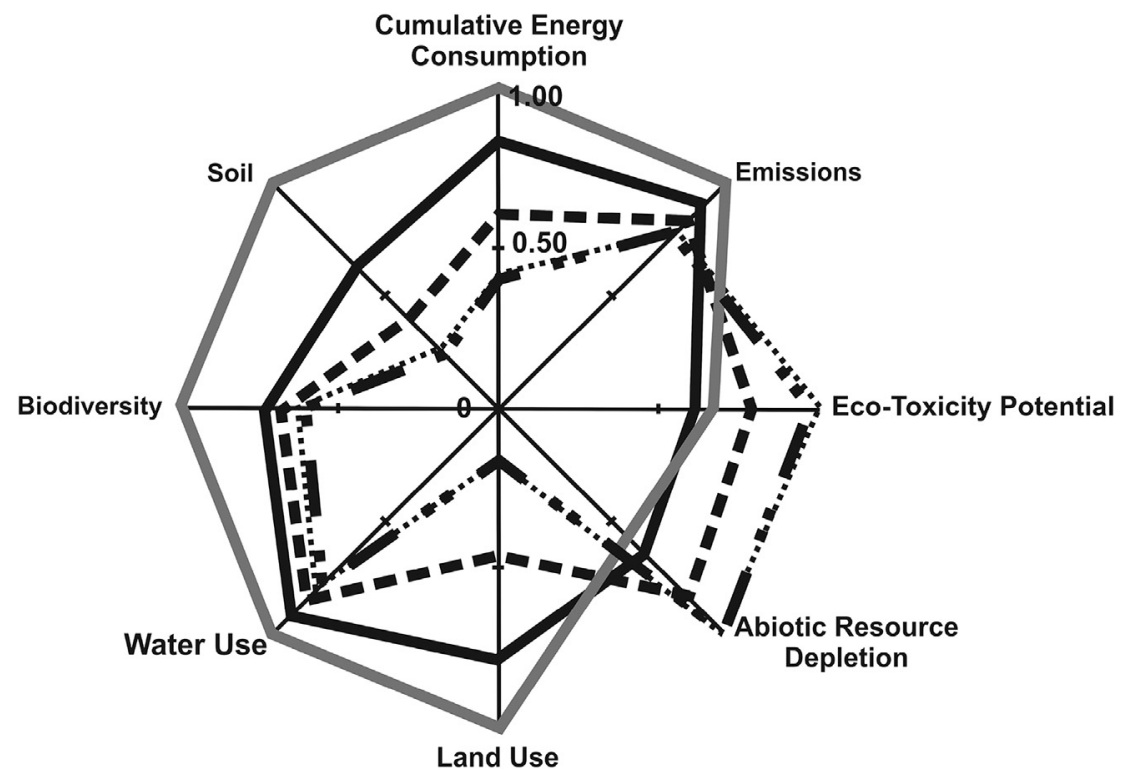

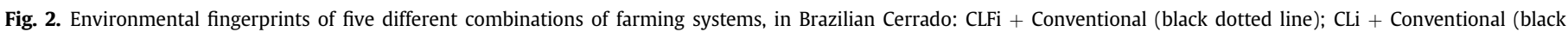
continuous line); Conventional (grey continuous line); CLFi + CLi + Conventional (1) (black dashed double dotted line); CLFi + CLi + Conventional (2) (black dashed line).

Table 4

Weighting factor and relevance for environmental categories of five different combinations of farming systems, in Brazilian Cerrado.

\begin{tabular}{|c|c|c|c|c|}
\hline & Environmental relevance factor & Social weighting factor & Geometric mean & Effective weighting factor \\
\hline & \multicolumn{4}{|c|}{$\%$} \\
\hline Emissions (including climate change) & 20.7 & 17.1 & 18.8 & 16.4 \\
\hline Energy & 12.4 & 10.4 & 11.4 & 9.9 \\
\hline Abiotic resource depletion & 14.9 & 12.6 & 13.7 & 12.0 \\
\hline Land use & 48.6 & 7.2 & 18.7 & 16.3 \\
\hline Eco-toxicity potential & - & 14.4 & - & 14.4 \\
\hline Water use & 3.4 & 13.1 & 6.7 & 5.8 \\
\hline Biodiversity & - & 13.8 & - & 13.8 \\
\hline Soil & - & 11.3 & - & 11.3 \\
\hline
\end{tabular}


the relative importance of each environmental and social impact. Societal weighting factors are constant (Table 4, column 3).

The effective weighting factors (Table 4, column 5) result from the geometric mean (column 4) of the relevance and the social weighting factor and normalization to $100 \%$; for those indicators where the relevance factor is not available, only the social factor is applied.

Aggregated scores shown in Fig. 1 are obtained by weighted summation of the normalized impact indicators for each alternative.

The effective weighting factors (Table 4, column 5) could be interpreted to determine the importance of each environmental impact category in relation to the priority of the other categories; higher values indicated greater importance in the context of this study. The indicator results for the most relevant environmental categories are discussed in detail below.

\subsubsection{Climate change potential}

Climate change potential (Fig. 3), expressed in $\mathrm{CO} 2$-equivalents (GWP100), was the most important indicator in the emissions impact category. The lowest emissions were associated with alternatives 1 and 4, in which CLFi was a major component. The purely conventional alternative 3 showed the worst performance.

The highest contribution to this impact was due to livestock emissions at the farm, followed by the industrial production of mineral fertilizers and field emissions from application of fertilizers. Other contributions from farming operations were the silage process and diesel combustion in machinery. The integrated alternatives showed lower potential impacts from direct livestock emissions, due to earlier cattle slaughter (compared to conventional system).

Carbon sequestration related to soil management on the farm was not considered in this assessment, due to lack of reliable data. The reported amounts of $\mathrm{CO} 2$ equivalent correspond to emissions generated by inputs production and use, together with process operations. Comparing the highly integrated combination (alternative 4 ) to the conventional combination (alternative 3), there was a decrease of $55 \%$ in climate change potential, corresponding to 2389 t of $\mathrm{CO} 2$ equivalent.

\subsubsection{Abiotic resources depletion}

The assessment of abiotic resources depletion is shown in Fig. 4.

The most integrated system (alternative 4 ) showed a $43 \%$ higher impact on resource depletion, compared to the conventional combination (alternative 3 ). Contribution analysis showed that this effect was due to increased use of zinc minerals in cattle feed and minerals in fertilizers applied in forestry in the integrated systems, with Zinc having a relatively high characterization factor in the abiotic resource depletion impact assessment method. Despite the moderate amounts of zinc used in the conventional and most integrated systems (122 kg and $243 \mathrm{~kg}$ in 7 years, respectively), the impacts were major contributors to the overall results of the present study.

In order to investigate the robustness of the results with regard to the parameter input of zinc, a sensitivity analysis was carried out, varying the amount of zinc additions in the calculations. In the extreme case of zero zinc additions, the rank order of alternatives in abiotic resource depletion would be inverted (Fig. 5), with the most integrated system (alternative 4 ) having the lowest impact potential for this impact category. The value obtained was $16 \%$ lower, compared to the highest impact potential, which was found for the conventional system (alternative 3 ).

In this scenario, the integrated systems showed lower impact in abiotic resource depletion potentials, compared to the conventional system, due mainly to lower consumption of oil, gas, and uranium (in the fertilizer pre-chain), which was only partially counterbalanced by higher demand for manganese and copper (used in the cattle feed pre-chain) in these systems. This, however, does not affect the rank order of the alternatives in the aggregated sustainability score (Fig. 1).

\subsubsection{Land use}

Results of the impact assessment related to land use are shown in Fig. 6. The major impact was related to the agricultural land use on the farms, including land use for calf raising and grazing.

This was mainly influenced by the different area productivities, which determined the land occupation of each system, for the defined functional unit. The results were also influenced by different system-specific characterization factors. In the impact assessment model, these factors rate the quality of land use in terms of biodiversity, or ecosystem damage potential (Köellner and

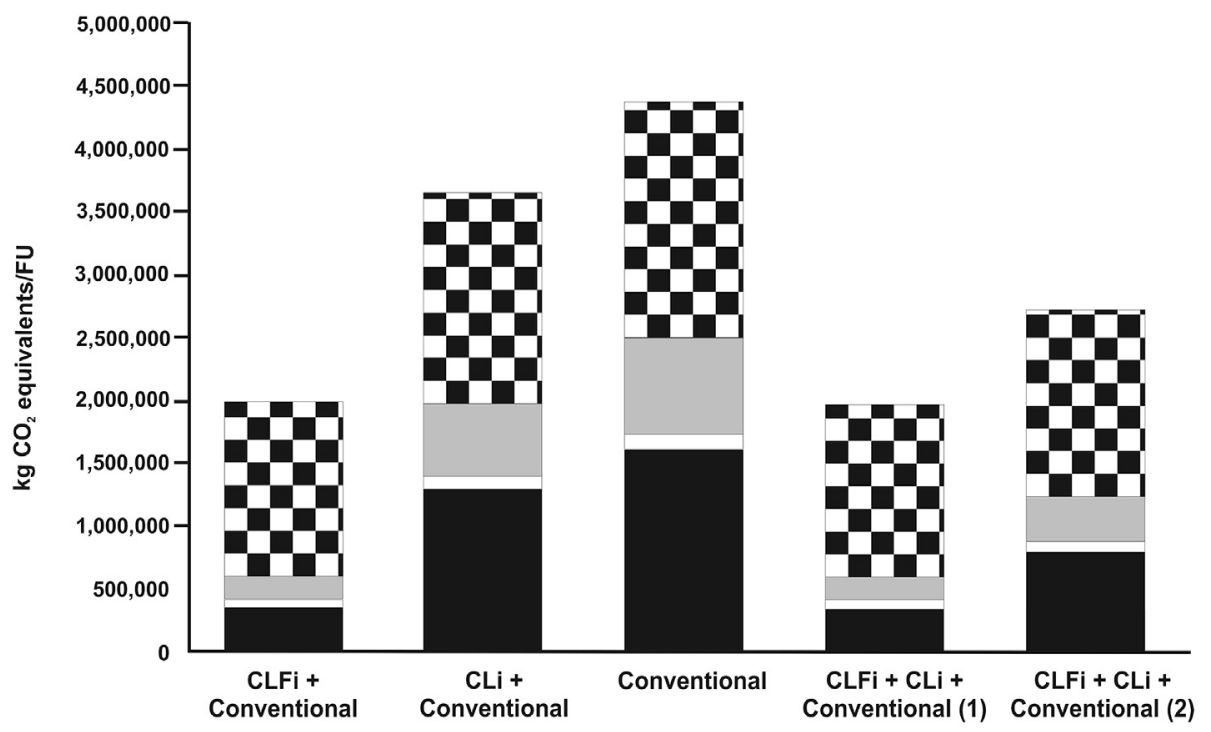

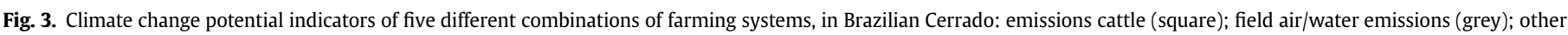
emissions, including silage, road transport, utilities, cattle feed, seeds and crop protection (white); fertilizers (black). 


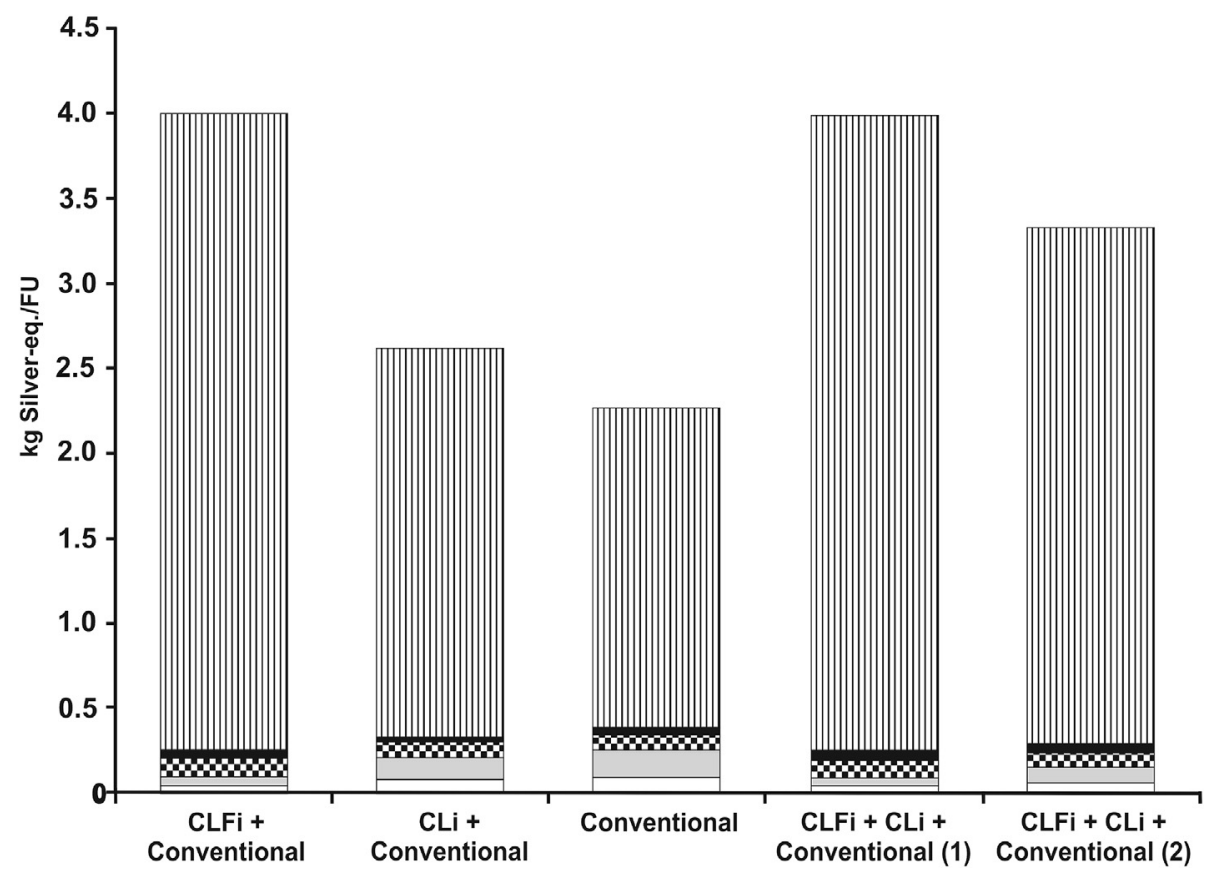

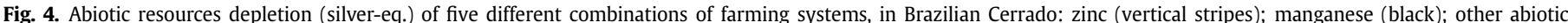

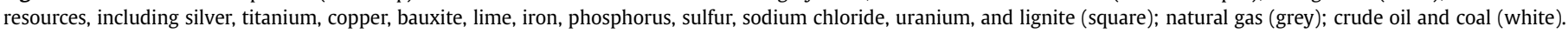

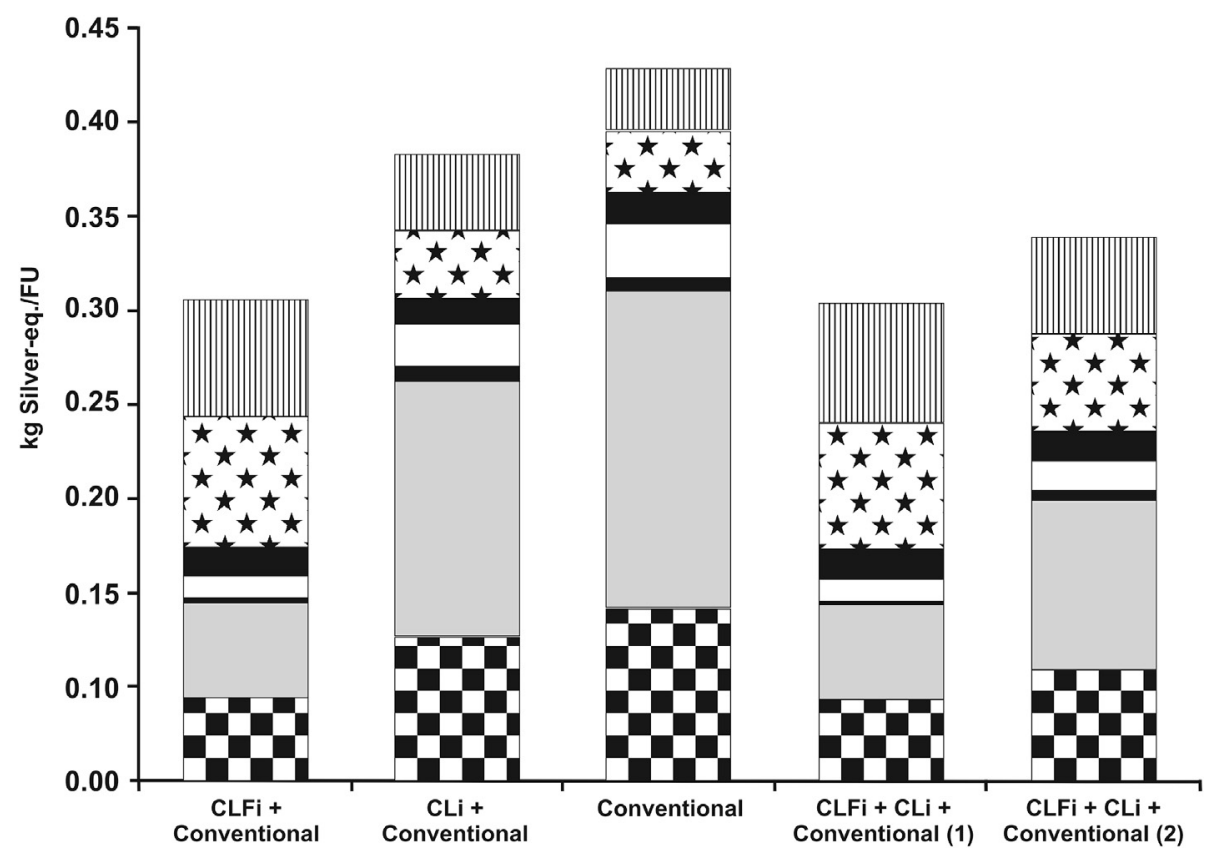

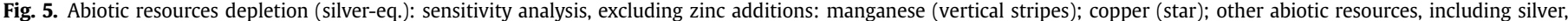
titanium, bauxite, lime, iron, phosphorus, sulfur, sodium chloride and lignite (black); uranium (white); natural gas (grey); crude oil and coal (square).

Scholz, 2007, 2008). The type of land use category under which the integrated crop-livestock-forest system falls has a more favorable characterization factor, compared to conventional arable, livestock and forestry areas. As a result of the combination of lower land occupation and a more favorable factor for quality of the land, the mostly integrated systems (alternatives 1 and 4 ) had $84 \%$ less impact, compared to the purely conventional system (alternative $3)$.
3.1.5. Assessment of soil and biodiversity management indicators specific for cropping and grazing areas

The above results for land use assessment (section 3.1.4) were based on prototypical land use classifications and corresponding characterization factors taken from the literature, which were unable to take into account specific management aspects of the different agricultural systems. Hence, a comparison of such systems based on these factors alone is incomplete. Assessment was 


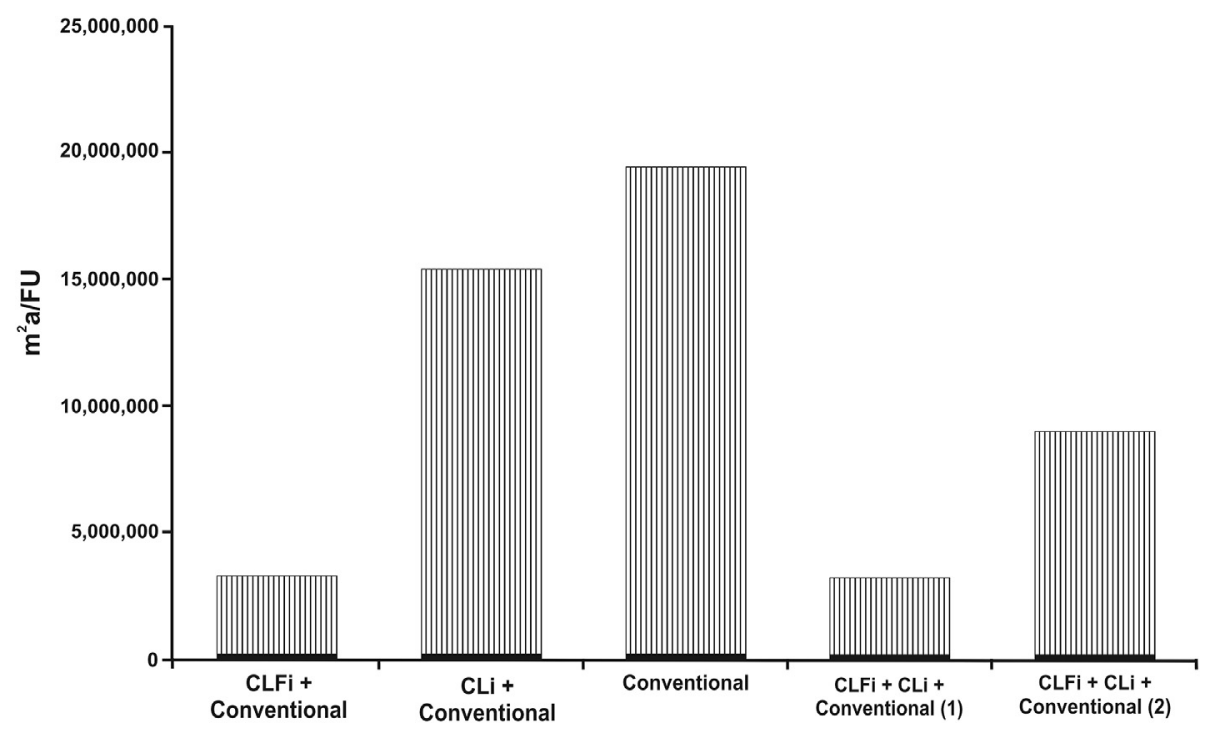

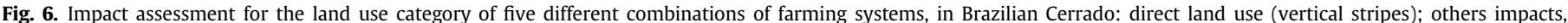
including road transport, utilities, cattle feed, seeds, crop protection and fertilizers (black).

therefore also made of soil management and biodiversity management criteria for agricultural and grazing areas.

The soil management criteria comprised nutrient balances, soil organic carbon, compaction potential and erosion potential. The results are shown in Fig. 7. The best overall performance was shown by alternative 4 , while alternative 3 (conventional system) gave the worst results for all the indicators analyzed. The main reasons for the better soil quality performance of alternative 4 could be attributed to lower erosion potential, higher soil organic carbon (SOC) levels and lower compaction potential. The worse erosion potential of the conventional system was mainly due to lower coverage of soil throughout the year in cropping areas, together with incomplete coverage of grazing areas, caused by low grass productivity. The differences in compaction potential were associated with differences in the soil organic carbon contents of the soils in the different systems. The significantly higher SOC contents of the integrated system soils provided them with greater resistance against compaction. The NPK nutrient input values were based on literature data and assumed equal fertilizer applications to the crops in the different cultivation systems. Hence, the variability among the systems was due to differences in the extraction of nutrients, which was associated with the differences in yields during the seven-year period analyzed.

The results obtained for the biodiversity management criteria are summarized in Fig. 8.

The biodiversity management criteria that showed differences

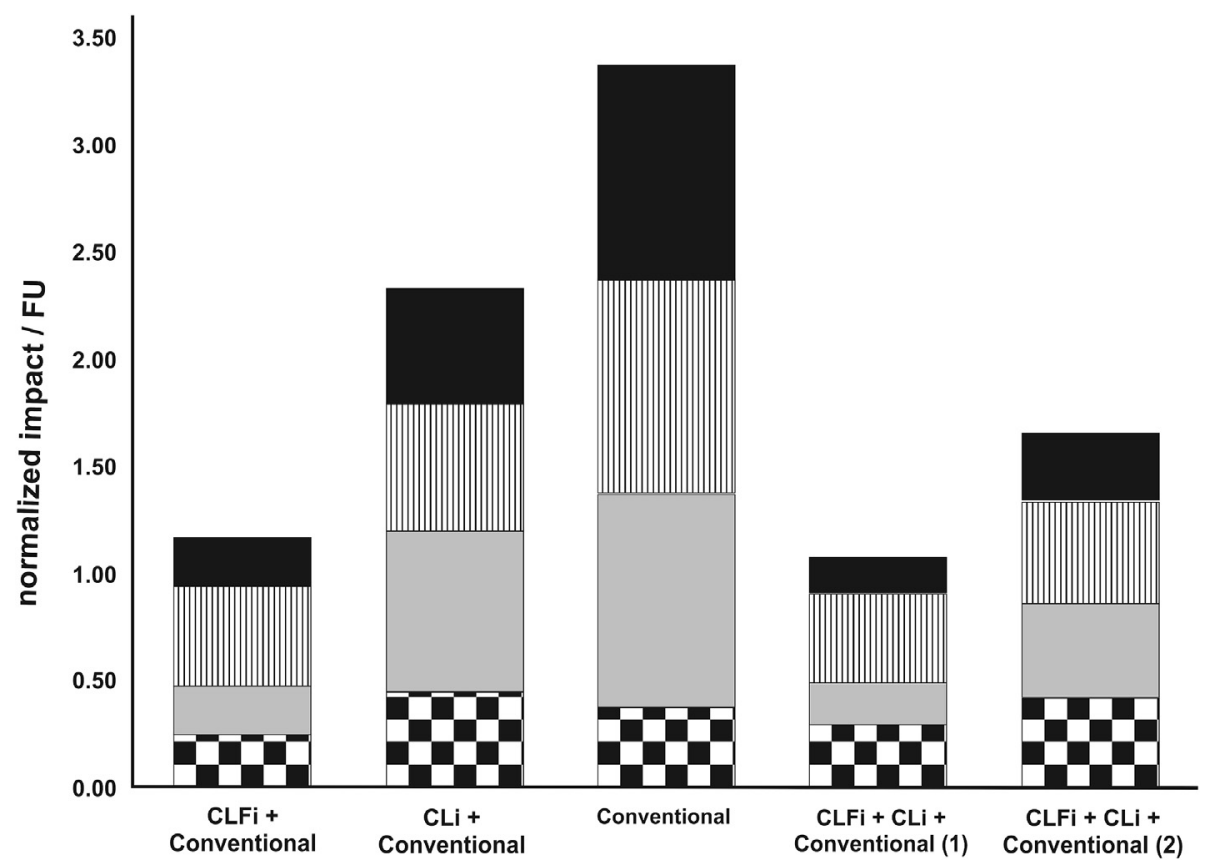

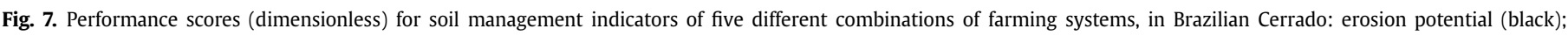
compaction potential (vertical stripes); soil organic carbon (grey); nutrient balance (square). 


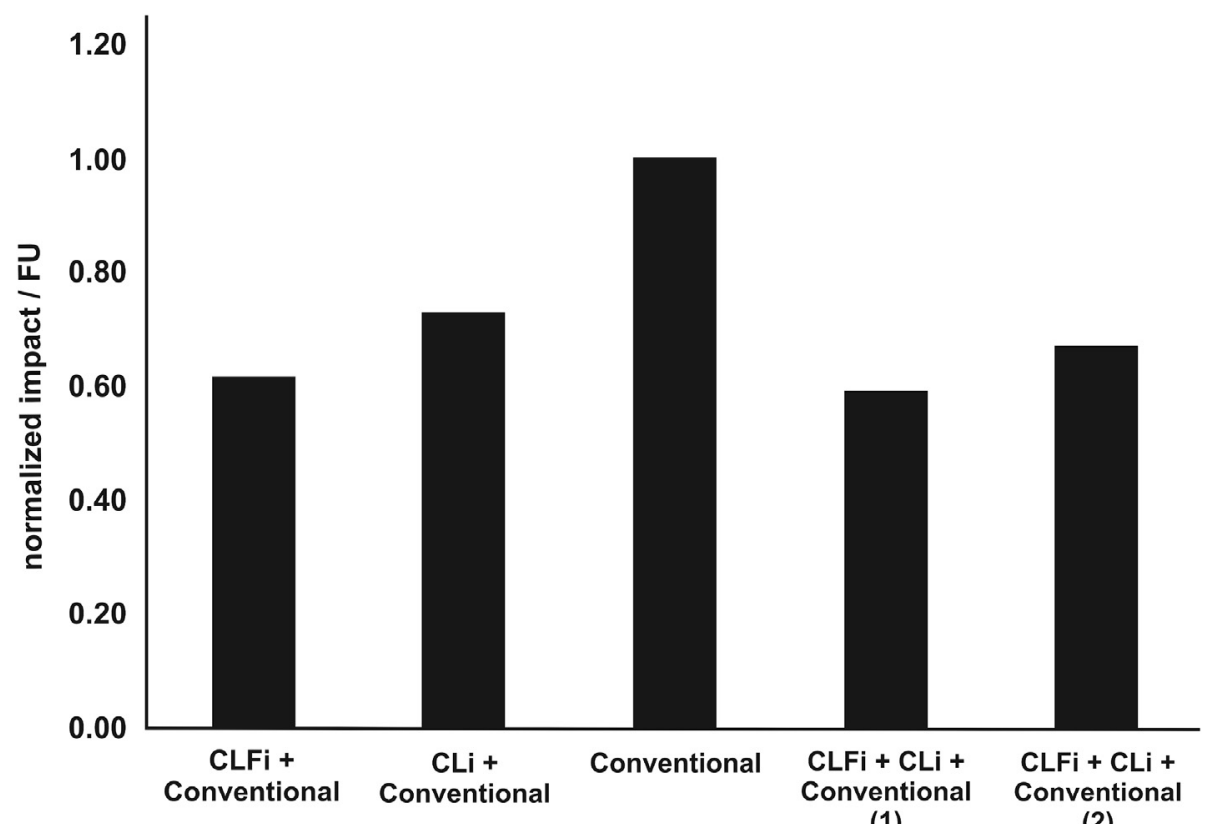

(1)

(2)

Fig. 8. Normalized biodiversity indicator values (dimensionless) of five different combinations of farming systems, in Brazilian Cerrado.

among the systems were crop rotation diversity, eco-toxicity potential and crop intermixing potential. The results for other criteria (coverage of protected areas, management intensity and nitrogen surplus) were similar for the various systems and hence did not contribute to the differences in impact.

The best performances were achieved with the integrated systems (alternatives 1 and 4), while alternative 3 showed the worst performance. In this assessment, the better performance of the integrated systems was associated with higher crop rotation diversity and lower eco-toxicity potential. The CLFi system showed the lowest eco-toxicity impact because this system only utilized crop protection during the two first years, when soy and corn were cultivated, together with Brachiaria, and for forestry, which only represented approximately $35 \%$ of the total area of the system. The crop protection application rates to the same crops in the different cultivation systems were assumed to be equal.

\subsection{Social impact assessment}

Social impacts are shown separately in Figs. 9 and 10 for the activities in the industrial manufacturing of inputs (pre-chain) and for agricultural activities at the farms. In the figures, the contributions from individual social impact metrics are grouped into stakeholder categories for employees, local and national community, and future generations.

Considering only the impacts of activities at the farm, the best

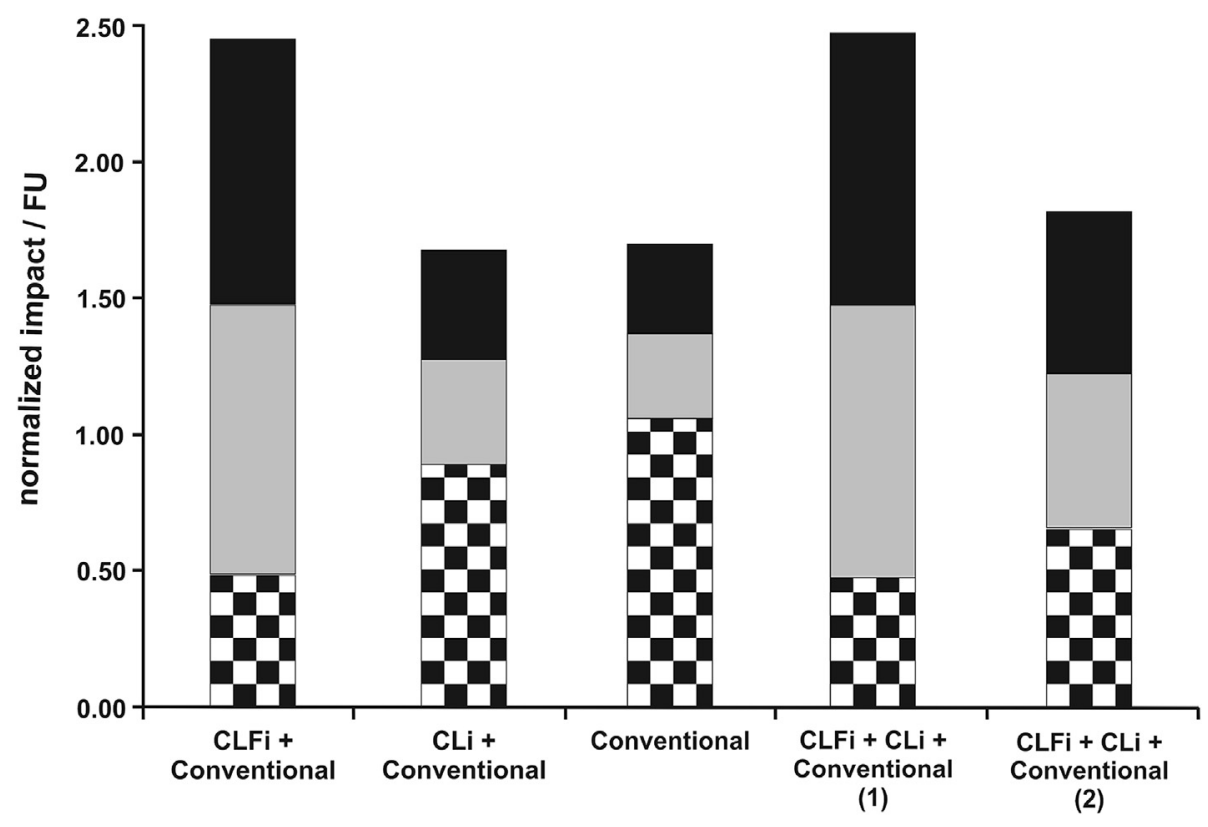

Fig. 9. Social analysis for the pre-chain activities (normalized impacts): future generation (black); local and national community (grey); employees (square). 


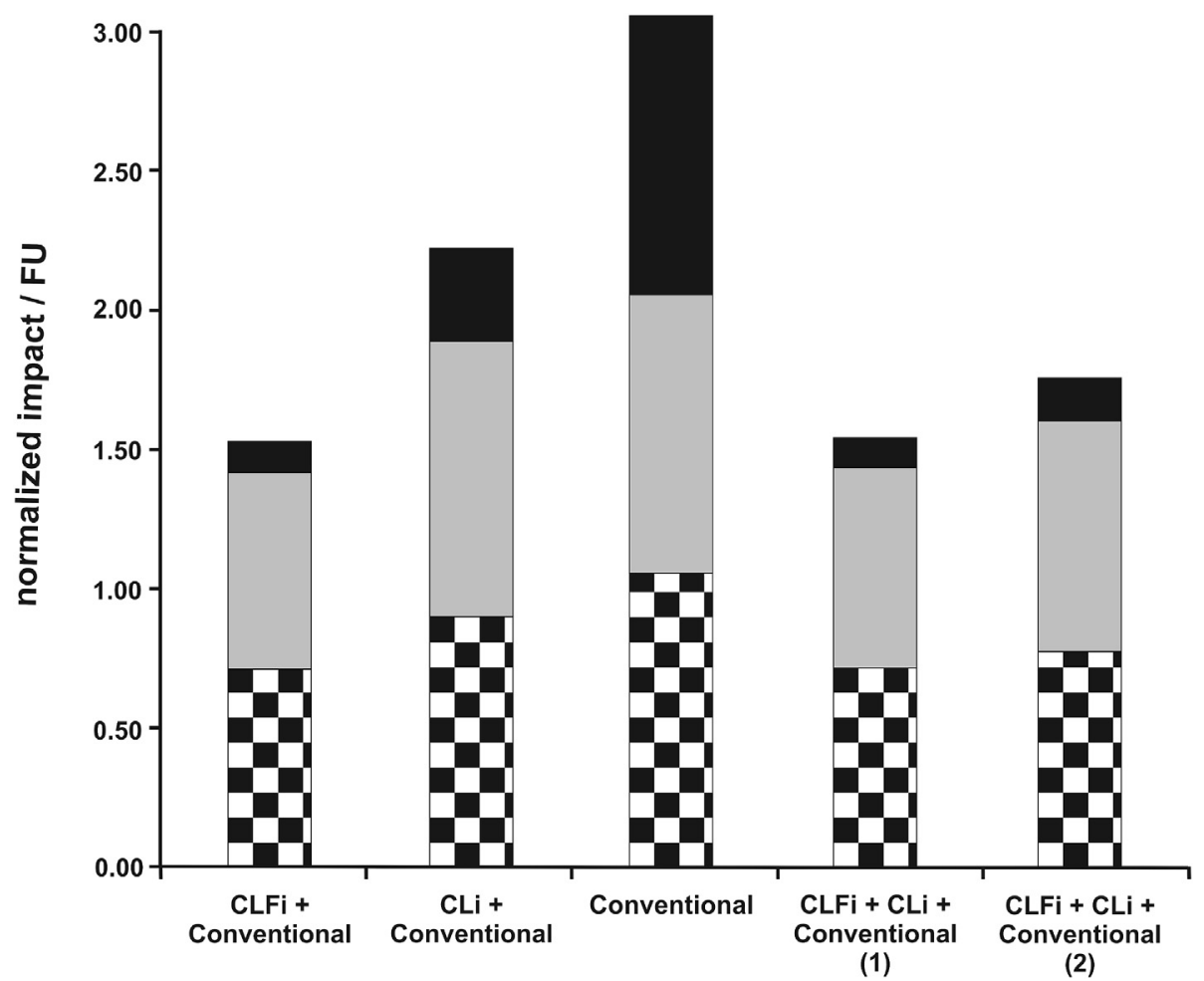

Fig. 10. Social analysis for the farm activities (normalized impacts): future generation (black); local and national community (grey); employees (square).

performance was achieved by the most integrated system (alternative 4) in all the categories evaluated (Fig. 10). However, considering only the pre-chain impacts, the best performances were observed for the conventional system (alternative 3 ) and the CLi/conventional system (alternative 2) (Fig. 9).

Further analysis of the pre-chain results (Fig. 9) at the process level (not shown) indicated that the highest contributions were associated with fertilizer production, followed by road transport. These activities have impacts that can be positive (wages/salary and benefits for employees) or negative (accidents, occupational diseases and toxicity). In conventional systems, the fact that more inputs were required led to greater effects in terms of the jobs and wages generated in industrial production, although negative indicators were also higher.

At the farm level (Fig. 10) the most integrated system showed the best performance, largely due to a higher level of qualified employment and professional training, which was reflected in the stakeholder category "local and national community". In addition, differences between the integrated and conventional systems were influenced by greater numbers of interns and trainees employed on the farms with integrated systems, which was reflected in the category "future generations". Finally, the integrated systems had higher expenditures for research and development as well as capital investments, which rated positively under "future generations".

The alternatives that included intermediate use of CLFi and CLi showed the best aggregated social scores, because they provided a balance of the pre-chain benefits of conventional systems and the farm level benefits of integrated systems. Nonetheless, the highly integrated combinations (alternatives 1 and 4) still showed better performance than the purely conventional system (alternative 3 ).

\subsection{Economic assessment}

An economic assessment was carried out on the basis of the total cost of production for each alternative, considering the complete production cycle of 7 years (Table 5). Inflation and changes in wages were considered. Machinery was considered to be rented (a common practice in the region), so there were no depreciation costs. The cost of land leasing was included.

The production costs for the amounts of food and energy established in this study was $54 \%$ lower for the most integrated system (alternative 4), compared to the conventional system (alternative 3). The integrated systems provided greater efficiency of land use throughout the year. The operational costs of such systems were lower, considering the output produced per functional unit (despite the higher cost per unit area), due to the higher productivity. Alternative 3 required a 6 -fold larger area of land for the conventional farming systems. Therefore, the greater area efficiency of the integrated systems resulted in lower costs of both inputs and land leasing.

Table 5

Total cost for each alternative per functional unit.

\begin{tabular}{|c|c|c|c|c|}
\hline $\begin{array}{l}\text { Alternative } 1: \\
\text { CLFi + Conventional }\end{array}$ & $\begin{array}{l}\text { Alternative } 2 \text { : } \\
\mathrm{CLi}+\text { Conventional }\end{array}$ & $\begin{array}{l}\text { Alternative 3: } \\
\text { Conventional }\end{array}$ & $\begin{array}{l}\text { Alternative 4: } \\
\text { CLFi }+ \text { CLi }+ \text { Conventional (1) }\end{array}$ & $\begin{array}{l}\text { Alternative 5: } \\
\text { CLFi }+ \text { CLi }+ \text { Conventional (2) }\end{array}$ \\
\hline \multicolumn{5}{|l|}{ US\$ } \\
\hline $394,975.00$ & $655,030.00$ & $812,186.00$ & $375,900.00$ & $502,830.00$ \\
\hline
\end{tabular}

Based on dollar quotation of December 31, 2014. 


\section{Conclusion}

Within the scope established in the present study, those production systems that included the highest proportions of the CLFi integrated production system were most socio-eco-efficient, followed by those that used $\mathrm{CLi}$, for all three sustainability dimensions, compared to conventional systems. These benefits are achieved with lower overall costs, highlighting the positive environmental, economic, and social impacts and benefits of practices that provide "sustainable intensification" and cleaner production.

Besides the significant potential reduction of greenhouse gas emissions, which is required and incentivized by Brazilian policy programs, the adoption of integrated systems can contribute to the growing global demand for food and energy, while minimizing environmental impacts, recovering degraded pasture areas, preserving forestland, optimizing costs, and promoting positive effects in society.

\section{Acknowledgements}

The authors thank the Fundação Espaço $\mathrm{ECO}^{\circledR}\left(\mathrm{FEE}^{\circledR}\right)$ and BASF for technical and financial support (scholarship). The authors also would like to thank the owner of Santa Brigida Farm and its staff who provided all data and a very helpful support during the field survey. The authors thank Brazilian Agricultural Research Corporation (EMBRAPA) for the technical assistance and the Crop-Livestock-Forest Integration Fostering Network and John Deere Brazil for the institutional support.

\section{Appendix A. Supplementary data}

Supplementary data related to this article can be found at https://doi.org/10.1016/j.jclepro.2017.10.063.

\section{References}

AGRIANUAL, 2010. Anuário da agricultura brasileira. AgraFNP, São Paulo. (in Portuguese).

Aidar, H., Kluthcouski, J., 2003. Evolução das atividades lavoureira e pecuária nos Cerrados. In: Kluthcouski, J., Stone, L.F., Aidar, H. (Eds.), Integração lavourapecuária. Embrapa Arroz e Feijão, Santo Antônio de Goiás, pp. 25-58 (in Portuguese).

Alexandratos, N., Bruinsma, J., 2012. World Agriculture towards 2030/2050: the 2012 Revision. FAO. ESA Working Paper No. 12-03, Rome.

Andres, C., Bhullar, G.S., 2016. Sustainable intensification of tropical AgroEcosystems: need and potentials. Front. Environ. Sci. 4, 5.

Balbino, I.C., Cordeiro, I.A.M., Oliveira, P., Kluthcouski, J., Galerani, P.R., Vilela, L., 2012. Agricultura sustentável por meio da integração lavoura-pecuária-floresta (iLPF). Inf. Agronômicas 138, 1-18.

Bommarco, R., Kleijn, D., Potts, S.G., 2013. Ecological intensification: harnessing ecosystem services for food security. Trends Ecol. Evol. 28, 230-238.

Boustead consulting limited. The Boustead Model 5.0.12. Available from: http://lca. jrc.ec.europa.eu/lcainfohub/tool2.vm?tid=186(Accessed 2 April 2013).

BRASIL. Ministério de Minas e Energia, 2014. Balanço Energético Nacional - BEN. Relatório Final 2007 a 2014. MME, Brasília. Available from: https://ben.epe.gov. $\mathrm{br} /$. (Accessed December 2015) (in Portuguese).

Cerri, C.C., Moreira, C.S., Alves, P.A., Raucci, G.S., Castigioni, B.A., Mello, F.F.C., Cerri, D.G.P., Cerri, C.E.P., 2016. Assessing the carbon footprint of beef cattle in Brazil: a case study with 22 farms in the State of Mato Grosso. J. Clean. Prod. 112, 2593-2600.

CML, 2010. CML-IA Characterization Factors 3.9. Institute of Environmental Sciences, Leiden University, Netherlands.

Costa, M.P., 2012. Avaliação da qualidade de solo do cerrado sob diferentes usos agrícolas, no município de Ipameri - GO. Instituto de Ciência e Tecnologia de Sorocaba, UNESP, São Paulo, p. 58 (in Portuguese).

Costa, M.P., 2015. Socio-eco-efficiency of Integrated and Non-integrated Systems of Crop, Forestry and Livestock in the Ipameri City, at Brazilian Cerrado. Thesis (Master's Degree in Environmental Sciences). Instituto de Ciência e Tecnologia, UNESP, Sorocaba, p. 166.

Costa, S.E.V.G.A., Souza, E.D., Anghinoni, I., Carvalho, P.C.F., Martins, A.P., Kunrath, T.R., Cecagno, D., Balerini, F., 2014. Impact of an integrated no-till croplivestock system on phosphorus distribution, availability and stock. Agr. Ecosyst. Environ. 190, 43-51.

de Figueiredo, E.B., Jayasundara, S., de Oliveira Bordonal, R., Berchielli, T.T., Reis, R.A.,
Wagner-Riddle, C., La Scala, N., 2017. Greenhouse gás balance and carbon footprint of beef cattle in three contrasting pasture-management system in Brasil. J. Clean. Prod. 142, 420-431.

EMBRAPA, 2010. Mercado e Comercialização. Sistema de Produção. Embrapa Milho e Sorgo, Sete Lagoa, MG (in Portuguese).

EMBRAPA - Empresa Brasileira de Pesquisa Agropecuária, 2013. Evolução de Sistema de Integração Lavoura-Pecuária-Floresta (CLFi): estudo de caso da Fazenda Santa Brígida, GO. Embrapa Cerrado, Planaltina, DF, p. 50 (Documentos/ Embrapa Cerrados). (in Portuguese).

FAO - Food and Agriculture Organization, 2014. FAO discute demanda Mundial Por Alimentos. Available from: https://www.fao.org.br/FAOddma.asp. (Accessed 19 January 2017) (in Portuguese).

FAOSTAT, 2015. Food and Agriculture Organization Statistics Division, Crops. Available from: http://faostat3.fao.org/. (Accessed 19 January 2017).

Garnett, T., Godfray, C., 2012. Sustainable Intensification in Agriculture. Navigating a Course through Competing Food System Priorities, Food Climate Research Network and the Oxford Martin Programme on the Future of Food. University of Oxford, UK.

Godfray, H.C.J., Beddington, J.R., Crute, I.R., Haddad, L., Lawrence, D., Muir, J.F., Pretty, J., Robinson, S., Thomas, S.M., Toulminet, C., 2010. Food security: the challenge of feeding 9 billion people. Science 327, 812-818.

Goedkoop, M., Heijungs, R., Huijbregts, M., Schryver, A.D., Struijs, J., van Zelm, R. 2013. ReCiPe 2008-A Life Cycle Impact Assessment Method Which Comprises Harmonized Category Indicators at the Midpoint and the Endpoint Level. Report I: Characterisation. Available from: http://www.leidenuniv.nl/cml/ssp/ publications/recipe_characterisation.pdf. (Accessed 19 January 2016).

IBGE - Instituto Brasileiro de Geografia e Estatística, 2015. Statistics on Crops and Livestock. Available from: http://www.ibge.gov.br/home/download/estatistica. shtm. (Accessed 6 March 2017).

IPCC, 2006. In: Egglestone, S., Buendia, L., Miwa, K., Ngara, T.K. (Eds.), Agriculture, Forestry and Other Land Use, vol. 4. IPCC National Greenhouse Inventories, Hayama, Japan.

IPCC - Intergovernmental Panel on Climate Change, 2007. Changes in atmospheric constituents and in radiative forcing. Forster P., Ramawamy, V. (Coord.). In: Solomon, S., Qin, D., Manning, M., Chen, Z., Marquis, M., Averyt, K.B., Tignor, M., Miller, H.L. (Eds.), Climate Change 2007: the Physical Science Basis. Contribution of Working Group I to the Fourth Assessment Report of the Intergovernmenta Panel on Climate Change. Cambridge University Press, Cambridge, United Kingdom and New York, NY, USA.

ISO - International standard organization, 2009a. Environmental Management -life Cycle Assessment: Principles and Framework. ISO14040, Geneva.

ISO - International standard organization, 2009b. Environmental Management - Life Cycle Assessment: Requirements and Guidelines. ISO14044, Geneva.

Köellner, T., Scholz, R., 2007. Assessment of land use impacts on the natural environment, Part 1: an analytical framework for pure land occupation and land use change. Int. J. Life Cycle Assess. 12 (1), 16-23.

Köellner, T., Scholz, R., 2008. Assessment of land use impacts on the natural environment, Part 2: generic characterization factors for local species diversity in Central Europe. Int. J. Life Cycle Assess. 13 (1), 32-48.

Kölsch, D., Saling, P., Kicherer, A., Grosse-Sommer, A., Schmidt, I., 2008. How to measure social impacts? A socio-eco-efficiency analysis by the Seebalance method. Int. J. Sustain. Dev. 11, 1-23.

Krozer, J., Vis, J.C., 1998. How to get LCA in the right direction. J. Clean. Prod. 6 53-61.

Lapola, D.M., Martinelli, L.A., Peres, C.A., Ometto, J.P.H.B., Ferreira, M.E., Nobre, C.A., Aguiar, A.P.D., Bustamante, M.M.C., Cardoso, M.F., Costa, M.H., Joly, C.A. Leite, C.C., Moutinho, P., Martins, A.P., Denardin, L.G.D.O., Borin, J.B.M. Carlos, F.S., Barros, T., Ozório, D.V.B., Carmona, F.D.C., Anghinoni, I., Camargo, F.A.D.O., Carvalho, P.C.D.F., 2017. Short-term impacts on soil-quality assessment in alternative land uses of traditional paddy fields in Southern Brazil. Land Degrad. Dev. 28, 534-542.

Martins, A.P., et al., 2017. Short-term impacts on soil-quality assessment in alternative land uses of traditional paddy fields in Southern Brazil. Land Degrad. Dev. 28 (2), 534-542.

Nemecek, T., Kägi, T., 2007. Ecoinvent Report 15. Life Cycle Inventories of Swiss and European Agricultural Production Systems. Swiss Centre for Life Cycle Inventories, Dübendorf.

Ogino, A., Sommart, K., Subepang, S., Mitsumori, M., Hayashi, K., Yamashita, T. Tanaka, Y., 2016. Environmental impacts of extensive and intensive beef production systems in Thailand evaluated by life cycle assessment. J. Clean. Prod. $112,22-31$.

Oliveira, P., 2010. Nitrogen Fertilization Management in Bean Cultivated after Maize-legumes Intercropping in the Crop-livestock Integration System in Brazilian Savannah. Thesis (PhD in Sciences). Escola Superior de Agricultura Luiz de Queiroz, USP, Piracicaba, p. 126 (in Portuguese).

Paes, M.X., Gianelli, B.F., Kulay, L.A., de Medeiros, G.A., Mancini, S.D., 2014. Life cycle assessment applied to municipal solid waste management: a case study. Environ. Nat. Resour. Res. 4 (4), 169-177.

Pfister, S., Koehler, A., Hellweg, S., 2009. Assessing the environmental impacts of freshwater consumption in LCA. Environ. Sci. Technol. 43, 4098-4104.

Rosenbaum, R.K., Bachmann, T.M., Gold, L.S., Huijbregts, M.A.J., Jolliet, O., Juraske, R. Koehler, A., Larsen, H.F., MacLeod, M., Margni, M., McKone, T.E., Payet, J. Schuhmacher, M., van de Meent, D., Hauschild, M.Z., 2008. USEtox-the UNEPSETAC toxicity model: recommended characterization factors for human toxicity and freshwater ecotoxicity in Life Cycle Impact Assessment. Int. J. Life 
Cycle Assess. 13, 532-546.

Saling, P., Kicherer, A., Dittrich-Kraemer, B., Wittlinger, R., Zombik, W., Schmidt, I, Schrott, W., Schmidt, S., 2002. Eco-efficiency analysis by BASF: the method. Int. J. Life Cycle Assess. 7, 203-218.

Scarpare, F.V., Hernandes, T.A.D., Simone Toni Ruiz-Corrêa, S.T., Kolln, O.T. Gava, G.J.C., Santos, L.N.S., Victoria, R.L., 2016. Sugarcane water footprint under different management practices in Brazil: tietê/Jacaré watershed assessment. J. Clean. Prod. 112, 4576-4584.

Schmidt, I., Meurer, M., Saling, P., Kicherer, A., Reuter, W., Gensch, C.0., 2004. Seebalance ${ }^{\circledR}$ : managing sustainability of products and processes with the socioeco-efficiency analysis by BASF. Greener Manage. Int. 45, 79-94.

Schoeneboom, J., Saling, P., Gipmans, M., 2012a. AgBalance ${ }^{\mathrm{TM}}$ : Technical Background
Paper. BASF SE, Limburgerhof, Germany. Available from: http://www.agro.basf. com/agr/AP-Internet/en/function/conversions:/publish/upload/sustainability/ AgBalance/307736_BASF_Tech-E_Paper-AgBalance.pdf. (Accessed 19 January 2017).

Schoeneboom, J., Saling, P., Gipmans, M., 2012b. NSF - BASF's AgBalance ${ }^{\mathrm{TM}}$ Methodology - August 2012. BASF SE, Ludwigshafen, Germany. Available from: http://www.nsf.org/newsroom/basfs-agbalance-methodology-august-2012/. (Accessed 19 January 2017).

van der Werf, H.M.G. Garnett, T., Corson, M.S., Hayashi, H., Huisingh, D., Cederberg, C., 2014. Towards eco-efficient agriculture and food systems: theory, praxis and future challenges. J. Clean. Prod. 73, 1-9. 